\title{
The importance of the BRICS group in the specialization of production and export competitiveness of North-East Brazil
}

Jevuks Matheus de Araújo, Lúcia Nunes de Barros Vitorio, Sergiany da Silva Lima and Danilo Raimundo de Arruda

\section{Summary}

This article seeks to identify and analyse the pattern of specialization in the export structure of North-East Brazil in 2003-2014, following the expansion of international trade with the BRICS countries (Brazil, Russian Federation, India, China and South Africa). The Aliceweb and Trademap databases are used to calculate the relevant indicators, namely the specialization coefficient, revealed comparative advantage, contribution to the trade balance, and degree of intraindustry trade. Trade with the BRICS countries led to exports being reorganized by specialization groups, thereby confirming a historical trend of comparative advantage in exports in the following product categories: food, tobacco and beverages; paper and pulp; chemicals; plastics and rubber; textiles; footwear and leather. Trade with the BRICS countries did not promote diversification or increase the technology content of the North-East's export structure.

\section{Keywords}

Foreign trade, regional development, exports, production specialization, competitiveness, measurement, trade policy, economic relations, China, India, Russia, South Africa, trade statistics, Brazil

\section{JEL classification}

F10, F14, F15

Authors

Jevuks Matheus de Araújo is a professor in the Department of Economics at the Federal University of Paraíba, Brazil. Email: jevuks@gmail.com.

Lúcia Nunes de Barros Vitorio is an economist working at the Serra Talhada branch of Banco do Nordeste, Brazil. Email: luciabarros2011@live.com.

Sergiany da Silva Lima is a professor in the Department of Economics at the Federal Rural University of Pernambuco, Brazil. Email: sergiany@yahoo.com.br.

Danilo Raimundo de Arruda is a professor in the Department of Administration of the Federal University of Paraíba - Campus III, Brazil. Email: dr_arruda@yahoo.com.br. 


\section{Introduction}

In the first decade of the twenty-first century, the BRICS ${ }^{1}$ countries joined forces to strengthen their foreign trade partnerships. Their participation in international trade had expanded considerably in the late twentieth century, with their share of the world market doubling between the 1990s and the early 2000 decade (Mathur and Dasgupta, 2013). This has influenced the international trade of North-East Brazil in the twenty-first century. Exports from North-East Brazil to the other BRICS ${ }^{2}$ countries grew by $4 \%$ between 2003 and 2009 to account for $15.45 \%$ of its total exports in the latter year; they then expanded further to $18.96 \%$ share in 2014. In total, exports to India grew by $80.96 \%$ and those to the Russian Federation by $73.45 \%$. Nonetheless, it was exports to China that had the largest trade impact, growing by $1,719.28 \%$ in the same period. In contrast, exports from North-East Brazil to South Africa accounted for just $1 \% .^{3}$

Given the growth of exports from the North-East to the BRICS countries, identifying the products with the largest share in this trade is fundamental for formulating sector-level economic policies. Understanding this trade would make it possible to strengthen the comparative advantages of products with market potential in the BRICS countries, particularly China owing to its economic weight in the bloc. For Hidalgo and Da Mata (2005):

Knowledge of the products that have a comparative advantage in international trade is extremely important, both when formulating growth strategies and for the economic well-being of a given region or country. Identifying such products makes it possible to establish robust strategies for the economy's international participation in an increasingly globalized and competitive world (Hidalgo and Da Mata, 2005, p. 967).

In late 2014, the BRICS countries accounted for $22 \%$ of global gross domestic product (GDP). Most of the bloc's GDP was produced by China (61\%), with smaller shares contributed by Brazil (14\%), India (12\%), the Russian Federation (11\%) and South Africa (2\%). China is also the bloc's leading exporter, accounting for $68 \%$ of the total, while Brazil is ranked fourth, with $6 \%$, ahead of only South Africa, which has a 3\% share. The Russian Federation and India are in second and third place, generating $14 \%$ and $9 \%$ of the bloc's exports, respectively. On average, BRICS exports grew by $251.2 \%$ between 2004 and 2014. Although Brazil and South Africa exported the least during the reporting period, their exports still more than doubled, increasing by $132.8 \%$ and $125 \%$, respectively. India's exports grew by $319.2 \%$, while China's increased by $294.9 \%$ and those of the Russian Federation expanded by $171 \%$. In 2014 , China absorbed $81.1 \%$ of Brazilian exports to the BRICS group, with the remainder distributed among the other countries as follows: India 9.3\%, the Russian Federation $6.1 \%$ and South Africa 3.6\%.

The economic and political scenario of the 1990s raised the status of the BRICS countries, and China became the world's second largest economy and its largest exporter in 2010. Brazil became the sixth largest economy in 2011, followed by India, which maintained high annual growth rates and established itself in ninth place in the global GDP ranking. The Russian Federation managed to recover as a result of economic stability, to become the world's eleventh largest economy; and South Africa rebuilt its national dignity by ending apartheid and consolidating democracy and the economy (Reis, 2012).

\footnotetext{
1 The BRICS are a country grouping consisting of Brazil, the Russian Federation, India, China and South Africa. The bloc is seen as a group of economies with rapid economic growth prospects.

2 Although the term "BRICS" is used in this article, the analysis actually refers to the North-Eastern region of Brazil and the other countries of the bloc except Brazil, namely the Russian Federation, India, China and South Africa.

3 This description was based on data from the Ministry of Development, Industry and Foreign Trade.
} 
Against this backdrop, increased participation in international commerce has boosted trade between the BRICS countries and led to a major restructuring of their export sectors over the past 19 years, with the share of commodities diminishing and that of higher value added products expanding (Kocourek, 2015).

The aim of this research is to analyse the impact of the BRICS countries on the product specialization and competitiveness of exports from the Brazilian North-East. The competitiveness of commodities produced in the North-East is classified by trade activity groups and the degree to which foreign trade takes place within rather than between industries.

The article is divided into five sections, including this introduction. Section II reviews the literature on the relations between international trade and the North-Eastern region, and section III describes the methodology used and the indices calculated. Section IV analyses and discusses the results, and the fifth and final section presents the main conclusions.

\section{International trade and North-East Brazil}

The economic development process in Brazil has been (and remains) characterized by socioeconomic inequalities; and regional disparity is a recurrent theme in Brazilian economic literature. Many authors ${ }^{4}$ have attempted to elucidate the historical, social, economic, cultural and institutional factors that underlie the persistence and deepening of regional inequalities in Brazil, in the context of the twenty-first century, especially as regards the international engagement of the country's different regions and, in particular, the North-East. ${ }^{5}$

Although it was one of the most dynamic areas of national territory during the golden age of sugarcane, growth in the North-East has been lacklustre in recent decades; and, despite making progress in its socioeconomic indicators, it has lagged well behind the other regions of the country, particularly the South-East and the South. ${ }^{6}$ This makes it important to analyse the how the BRICS countries have influenced the economy of the North-East and their role in the reorganization of its production and export competitiveness.

Guimarães Neto (1997) notes that, during Brazil's colonization period, the economy of the North-East was foreign-trade-oriented, based mainly on sugarcane monoculture. When this declined, it was replaced by other crops including cotton, tobacco and cocoa. This export-oriented period lasted until the mid-nineteenth century. Then, from the end of the nineteenth century until the first half of the twentieth, with the crisis of the North-East export sector and emergence of manufacturing industry in the South-East of the country (especially in São Paulo), the North-East strove to engage with this market to sell its surpluses, becoming the chief supplier of cotton to the nascent textile industry in São Paulo. In the 1930s, however, the latter's non-durable consumer goods industry made advances that caused the North-East to lose the market not only outside but also within the region. The situation worsened in the 1950s, when it was invaded by heavy industry from the South-East.

Guimarães Neto (1997) also notes that dissatisfaction expressed by social and political movements spawned fiscal and financial studies and incentives, such that, from 1975 onward, the North-East was able to mitigate regional disparity by increasing its industrial activity and promoting its decentralization

4 Almeida and Araújo (2004), Diniz (2009), Furtado (1997), Guimarães Neto (1997) and Gomes and Vergolino (1995).

5 Hidalgo (2000), Feistel and Hidalgo (2007 and 2011), Hidalgo and Da Mata (2005) and Carvalho, De Melo Caldas and Lima (2013).

6 To illustrate this disparity in gross domestic product (GDP), the South-Eastern region accounted for $55.2 \%$ of national GDP in 2012, followed by the South with 16.2\%, the North-East with 13.6\%, the Centre-West with $9.8 \%$ and the North with $5.3 \%$. In the same year, $76.6 \%$ of national GDP was concentrated in just eight states (São Paulo, Rio de Janeiro, Minas Gerais, Rio Grande do Sul, Paraná, Santa Catarina, the Federal District and Bahia) which, with the sole exception of Bahia, belong to the South and South-Eastern regions (see [online] http://www.valor.com.br/brasil). 
across the country. Nonetheless, the capital employed came from the consolidated industry of the South-East and was allocated to activities and regions selected by it, specifically the most dynamic ones; and it occupied spaces in the activities of the South-East. The result was that modernized areas were created in the midst of zones of stagnation. ${ }^{7}$

To illustrate the inequality of the North-East, Gomes and Vergolino (1995) used economic criteria to divide the region into the following four subregions according to their dynamics and activities:

(i) Metropolitan region: where the large industrial complexes are located and on which the greatest fiscal incentives, especially federal ones, were targeted. The region encompasses Fortaleza (State of Ceará), Recife (State of Pernambuco) and Salvador (State of Bahia), where production is based mainly on the textile, metal-mechanical, chemical, paper and pulp, and food product sectors;

(ii) Forest area (Zona da Mata): characterized by significant agricultural and manufacturing activity;

(iii) Irrigation hubs: where the main irrigation areas of the North-East are concentrated;

(iv) Semi-arid region: composed of the agreste region (an area of transition between the semi-arid sertão and the mata zone) and the sertão (a large area with a semi-arid climate); it has low-productivity subsistence agriculture, linked to extensive cattle raising.

Lima (1998) notes that, in the late 1980s, Brazil eased control over imports, thereby altering the course of economic policy following several decades of import-substitution industrialization. This trade liberalization process benefited the South and South-East more than the North-East, both because of the proximity of these regions to the Southern Common Market (MERCOSUR), and because of the tariff hierarchy that protected the durable and capital goods that are characteristic of the South-South-East axis. Analysing the period from 1990 to 2005, Feistel and Hidalgo (2011) note that exports from the North-East grew by less than those of Brazil as a whole (by 198\% compared to 276\%), while imports posted equivalent growth.

In order to identify the most appropriate strategy for the international engagement of the North-Eastern region, Hidalgo (2000) used indices of revealed comparative advantages and coverage coefficients to identify the products that are the region's strengths in international trade, along with the sources on which these advantages are based and the role of natural resources, in a period spanning 1975 to 1995 . The results showed that the region has comparative advantages in certain manufactured products, such as petrochemicals, non-metallic minerals, basic metals and cellulose; and that its regional specialization is based heavily on natural resources.

Feistel and Hidalgo (2007) analysed the evolution of the North-Eastern region's specialization model between 1990 and 2004, with a view to determining whether international trade makes it possible to exploit comparative advantages. The methodology used involved collecting data on the income generated in each sector of production and on its natural resource requirements. The endowment triangle method is used to calculate each sector's direct and indirect input requirements, with outputs classified by factor intensity. The authors applied input-output analysis to the factor composition of the region's foreign trade and found that, although there are products in the region that make intensive use of both natural resources and capital, the most abundant factor is labour. During the period under

\footnotetext{
7 More than 60 years ago, the Working Group for the Development of the North-East (GTDN), led by Celso Furtado, launched discussion on the Brazilian regional issue by identifying industrialization and technology as the pillar of the Plan of Action (1959) for state intervention in the North-Eastern region. The structural problems identified in the GTDN diagnosis, which placed the economy of the North-East far below Brazil's economic and social development (the latter already being seen as peripheral), were the following: (i) regional income inequality; (ii) low rate of growth of GDP and GDP per capita; (iii) transfer of resources for private sector investment from the North-East to other regions of the country, in search of better investment opportunities; (iv) development based exclusively on the commodity export sector, for example: sugar, cotton, cocoa, tobacco, leather, oilseeds and some minerals; (v) regressive tax system; and, (vi) semi-arid region characterized by an extensive livestock economy and low-yield agriculture which, in periods of drought, has a disproportionate impact on the weakest part of the North-Eastern economic system, namely subsistence agriculture (GTDN, 1959).
} 
review, the share of capital-intensive exports increased by over $300 \%$, while that of labour-intensive exports flatlined. The authors then suggested that a failure to exploit comparative advantages may account for the slow growth of the region's exports.

To determine which products from the North-Eastern region and the State of Pernambuco had a comparative advantage in the international market between 1996 and 2002, Hidalgo and Da Mata (2005) used revealed comparative advantage, an indicator of contribution to-the trade balance and an index of the degree of intraindustry trade. The results revealed comparative advantages for the North-East in the categories of food, tobacco and beverages; chemicals; plastics and rubber; paper and pulp; textiles; and metals; and advantages for Pernambuco in the food, tobacco and beverages; chemicals; plastics and rubber; and textile groups.

In the aforementioned study, the index measuring the degree to which trade occurs within, rather than between, industries showed that, in the North-Eastern region, intraindustry trade is significant in inorganic chemicals but less so in footwear and sugar. In Pernambuco, sugar displays a low level of intraindustry trade, while the opposite is true for plastics, rubber, articles of stone, plaster and cement. In that state, the products that make a positive contribution to the trade balance are food, tobacco and beverages; plastics and rubber; footwear and leather; textiles; non-metallic minerals; and others. In the North-Eastern region, positive contributors pertain to the following categories: food, tobacco and beverages; chemicals; plastics and rubber; footwear and leather; wood and charcoal; paper and pulp; non-metallic minerals; basic metals; and others.

Feistel and Hidalgo (2011) studied the nature of, and changes in, the structure of trade between the North-Eastern region and China, along with the products that displayed comparative advantages in 1992-2009. The authors applied indices of product concentration, revealed comparative advantage, revealed symmetric comparative advantage, and intraindustry trade. This enabled them to verify a growing share for the food and beverage category, followed by the mineral and non-metallic mineral groups, which are subject to high levels of volatility. The machinery and equipment, basic metals and chemicals categories became less competitive during the period analysed. In contrast, the pulp and paper category was the only sector to show a clear comparative advantage and was the mainstay of the North-East's trade with China, accounting for over half of its exports in the latter year. The North-East's trade with China proved to be between industries, or interindustry.

To analyse trading relations between the North-Eastern region and MERCOSUR, Carvalho, De Melo Caldas and Lima (2013) used the specialization coefficient, revealed comparative advantages, the trade complementarity index, ${ }^{8}$ the trade effectiveness index, ${ }^{9}$ and the hypothesis of achieved potential (data for 2010). ${ }^{10}$ The results revealed concentration, in both the export and the import structure, with intraindustry characteristics. They also identified revealed comparative advantages in 26 of the 96 items analysed, and trade potential for 30 industrial sectors, 18 of which are considered underexploited. No sector was found to be trade-effective.

Marques and others (2017) analysed the competitiveness of Brazilian cashew exports in 2000-2011, relative to that of the world's leading cashew producers. The states of Ceará, Piauí and Rio Grande do Norte, which are located in Brazil's North-Eastern region, are the main producers of cashew nuts in the country. The methodology used included the revealed-comparative-advantage index, the performance indicator ${ }^{11}$ and the constant-market-share model. ${ }^{12}$ All of the calculated indicators identified the loss

8 This index analyses the potential for trade between the exporting region and the trade partner in question. Values above 1 indicate the existence of trade potential, while values below 1 suggest that such potential does not exist.

9 This index evaluates the effectiveness of trade between two regions. A value below 1 indicates that trade potential is not being fully exploited.

10 This index measures the quantity of exports needed for the trade effectiveness index to have a value of 1.

11 This indicator shows whether a country's exports to the world decreased or increased in a given period.

12 This model captures the effect of the variation in exports as a function of changes in the economy's export structure by destination. 
of competitiveness of Brazilian cashew, together with a relative loss of market share. While the volume of Brazil's exports increased, cashew exports from Viet Nam and Côte d'Ivoire increased significantly, thereby taking market share from competitor countries.

Hidalgo and Sales (2014) analyse the effects of trade on the distribution of income, finding that wages in the North and North-East are lower than in other parts of Brazil. The North and North-Eastern regions tend to be poorly integrated into domestic and international trade, so further regional analysis is needed to promote greater integration, since trade favours higher skills and better wages.

According to data from the Brazilian Institute of Geography and Statistics (IBGE), in 2009 roughly $70 \%$ of formal workers in the North-East earned no more than twice the minimum wage. The same source also reports a per capita GDP situation similar to that prevailing in the 1950s, when the per capita income of the North-East was just one third of that of the South-East (35\% in 2009).

In recent decades, the North-East, which is socioeconomically fragile, has been targeted by a set of policies related to a variety of projects. These include the refineries in Suape (Pernambuco) (now operating); the trans-North-East railway; the São Francisco River transposition; the petrochemical industry in Pernambuco; port investments in Pernambuco, Bahia and Ceará; the expansion agribusinesses and the issue of food security, investments and wind energy in Bahia; prospects for wind energy and irrigated fruit farming in the semi-arid North-East; pharmaceutical investments in Pernambuco and investments in the automobile industry in Bahia and Pernambuco.

Analysing data for 1996-2004, Carvalho and Alves (2006) highlight the concentration of exports from the North-East to the Russian Federation, in which the states of Alagoas and Pernambuco are the leading exporters of commodities to that country. In this connection, half of the North-East's exports were concentrated in Bahia. Exports of North-Eastern products to China, one of Brazil's main BRICS trading partners, increased from $2 \%$ in 2000 to approximately $12 \%$ in $2010 .^{13}$

This shows the need to consider the importance of the BRICS countries in the reorganization of production in the North-East and in the region's external competitiveness. Although it displays relative indicators of external engagement, mainly in terms of exports of natural products to those countries (the fastest growing trade partners in the last decade), the challenges and opportunities posed for the North-Eastern region are enormous, especially in terms of setting up a competitive and diversified industrial complex.

\section{Methodology}

The level of commodity specialization in the Brazilian North-East, is measured by calculating the specialization coefficient (SC); and the competitiveness of the region's exports to the BRICS is analysed using indicators of revealed comparative advantage (RCA) and contribution to the trade balance (CTB). The analyses focus on the period 2003 to 2014, and the degree of intraindustry trade is measured for the latter year. This period is justified by the economic rise of the BRICS in the first decade of the twenty-first century. It should be noted that 2003 also marks the start of a growth cycle in the Brazilian economy that was strongly associated with the expansion of exports.

\section{Specialization coefficient (SC)}

By mathematical construction, the product $i$ specialization coefficient $\left(S C_{i}\right)$ represents the share of exports of that good in a region $j\left(X_{i j}\right)$ in total exports from the same region $\left(\sum_{i}^{n} x_{i j}\right)$. According to Carvalho, De Melo Caldas and Lima (2013) this coefficient can be measured through equation 1.

\footnotetext{
${ }^{13}$ See [online] http://aliceweb.desenvolvimento.gov.br.
} 


$$
S C_{i j}=\frac{x_{i j}}{\sum_{i}^{n} x_{i j}}
$$

A high value for $S C$ indicates that the region's exports are concentrated or specialized in terms of products, whereas a low value signals the absence of export specialization, in other words a wide diversity of products in the regional export basket. The $S C$ index is also used to measure the region's specialization by export destination, by estimating the share of exports of product $i$ from region $j\left(x_{i j}\right)$ in the region's total exports $\left(x_{j}\right)$ to a specific destination (Feistel and Hidalgo, 2011).

\section{Revealed comparative advantage (RCA)}

The revealed comparative advantage index was originally developed by Balassa (1965). Only import values were included in its composition, on the grounds that imports are affected by the protectionist policies implemented by the trade partners in question. The $R C A$ indicator measures the share of exports of product $i$ from region $j$ in the region's total agricultural exports $\left(X_{i j} / X_{j}\right)$ divided by the export share of product $i$ relative to the total agricultural output of the rest of the world $\left(X_{i j z} / X_{z}\right)$.

However, the revealed comparative advantage index for commodity $i$ of the North-Eastern region $j$ $\left(R C A_{i j}\right)$ is used to capture the comparative advantage of exports from the North-East to the BRICS countries, as expressed in equation 2.

$$
R C A_{i j}=\frac{x_{i j} / x_{i z}}{x_{j} / x_{z}}
$$

Thus, $X_{i j} / X_{j}$ is the export share of the commodity $i$ in the total agricultural exports of the Brazilian North-East; while $X_{i j z} / X_{z}$ is the share of the same commodity $i$ in total agricultural exports from the rest of the world.

When $R C A_{i j}>1$ product $i$ is said to have a revealed comparative advantage in the region. In the opposite case, $R C A_{i j}<1$ means that product $i$ reveals a comparative disadvantage in the reference region $j$.

\section{Index of contribution to the trade balance (CTB)}

The index of contribution to the trade balance is also an indicator of revealed comparative advantage. This indicator was developed by Lafay (1990) to demonstrate the comparative advantage of commodity $i$ in relation to the trade balance of economy $j$, as expressed in equation 3 .

$$
\operatorname{CTB}_{i j}=\frac{100}{(X+M) / 2}\left[\left(X_{i}-M_{i}\right)-(X-M) \frac{\left(X_{i}+M_{i}\right)}{(X+M)}\right]
$$

The variables $X_{i}$ and $M_{i}$ represent exports and imports of good $i$, respectively. Therefore, the difference between the product $i$ trade balance $\left(X_{i}-M_{i}\right)$ and the trade balance weighted by the share of commodity $i$ in foreign trade $\left((X-M) \frac{\left(X_{i}+M_{i}\right)}{(X+M)}\right)$ determines the sign of the respective $C T B_{i j}$.

The interpretation is analogous to that of the RCA indicator: when $C T B_{i j}>0$ product $i$ is said to have a revealed comparative advantage; and, conversely, when $C T B_{i j}<0$, it is said to have a comparative disadvantage. This index makes it possible to identify the products with the greatest advantage in the composition of the region's trade balance. 


\section{Intraindustry trade index}

The Grubel-Lloyd (GL) index of intraindustry trade is used to measure the extent to which an economy's foreign trade takes place within industries. Its mathematical construction is suggested as a measure of the trade pattern (Grubel and Lloyd, 1975).

$$
G L=1-\frac{\sum_{i}\left|X_{i}-M_{i}\right|}{\sum_{i}\left(X_{i}+M_{i}\right)}
$$

The $G L$ index varies from 0 to $1(0 \leq G L \leq 1)$. Variables $X_{i}$ and $M_{i}$ represent exports and imports of good $i$, respectively. When $G L=0$, trade is said to be interindustry, in other words determined by the abundant factor as described in the Heckscher-Ohlin model. Conversely, where $G L=1$, trade is understood to be intraindustry, or characterized by the exchange of products within the same sector using similar technologies and economies of scale (Caldarelli and Miranda, 2009). In practice, the midpoint of the range of values is used as a rule of thumb for interpreting the results of the $G L$, as suggested by Hidalgo (1993). Thus, when $0,5<G L \leq 1$ trade is intraindustry and when $0 \leq G L \leq 0,5$ trade is interindustry.

\section{Presentation of variables and data sources}

The methodology used in this research has the specific purpose of measuring the specialization coefficient (SC), competitiveness (RCA and CTB) and the pattern of commodity trade in the Brazilian North-East. By mathematical construction all indicators are determined exclusively by foreign trade variables, as follows:

(i) The specialization ratio (SC) is composed of the variable representing exports of domestic commodities to the BRICS countries;

(ii) The revealed comparative advantage $(R C A)$ index consists of the variables representing commodity exports and total exports from the North-Eastern region to the BRICS countries, relative to commodity exports and total exports from the rest of the world;

(iii) The index measuring contribution to the trade balance (CTB) is composed of the variables representing commodity and total exports and imports from (to) the Brazilian North-East to (from) the BRICS countries;

(iv) The sector level Grubel-Lloyd intraindustry trade index (GL) is also measured by the variables representing exports and imports of the region's commodities to and from the BRICS countries.

The level of data aggregation is conditioned by availability constraints in the databases consulted, namely Aliceweb (Government of Brazil, n/d) and Trademap (ITC, n/d). Aliceweb collects monthly data from the Ministry of Development, Industry and Foreign Trade and makes it possible to consult data on the exports and imports of Brazil, and its states and regions, of national origin and destined for other countries, economic blocs, agreements or partnerships around the world. ${ }^{14}$ Trademap gathers information from the World Trade Organization (WTO), with annual data on the destination and origin of products for countries, blocs, agreements and alliances. The data are classified through the Harmonized System and coincide with those available in Aliceweb2 (Government of Brazil, n/d).

\footnotetext{
${ }^{14}$ The variables in the Aliceweb database are organized according to the Brazilian Nomenclature of Markets (NBM) and the MERCOSUR Common Nomenclature (NCM), as noted by Thorstensen and others (1994, pp. 50-51), cited in Feistel and Hidalgo (2011).
} 


\section{Analysis of the results}

The results of this research are reported in five subsections. The first analyses the evolution of foreign trade between the North-Eastern region of Brazil and the BRICS countries. The second identifies regional products traded with the BRICS countries by analysing the export specialization coefficients. The third and fourth subsections assess the competitiveness of exports from the North-East to the BRICS countries, compared to the rest of the world, by analysing the exported products' revealed comparative advantage and contribution to the trade balance. The last subsection discusses the degree to which exports are intraindustry. In general, China emerges as the main importer of products from the Brazilian North-East, followed by the Russian Federation. The region clearly specializes in low value-added agricultural products that are highly competitive externally. The profile of North-Eastern exports to the BRICS countries also shows interindustry characteristics, with production reflecting the advantage based on relative factor endowments.

\section{Trend of exports from the Brazilian North-East to the BRICS countries}

In 2003, exports from North-East Brazil to the BRICS countries represented just $4 \%$ of the region's exports to the rest of the world. In 2009, this share had grown to reached $15.45 \%$, and by the end of 2014 it stood at $18.96 \%$. Data show that the region's exports to the rest of the world shrank by roughly $50 \%$ in value terms in 2009, as the uptrend in export volume that had lasted since 2003 went into reverse. This was one of the consequences of the 2007 sub-prime mortgage crisis, which triggered a financial crisis in the United States in 2008. ${ }^{15}$ Nonetheless, this did not affect trade between the Brazilian North-East and the BRICS countries, which has been expanding since early 2003. Unlike exports to the rest of the world, influenced by sales to the United States, exports to the BRICS countries grew by roughly 18\% in 2009 alone (see figure 1).

Figure 1

Share and rate of growth of exports from North-East Brazil to the BRICSa countries, relative to its exports to the rest of the world, 2003-2014

(Percentages)

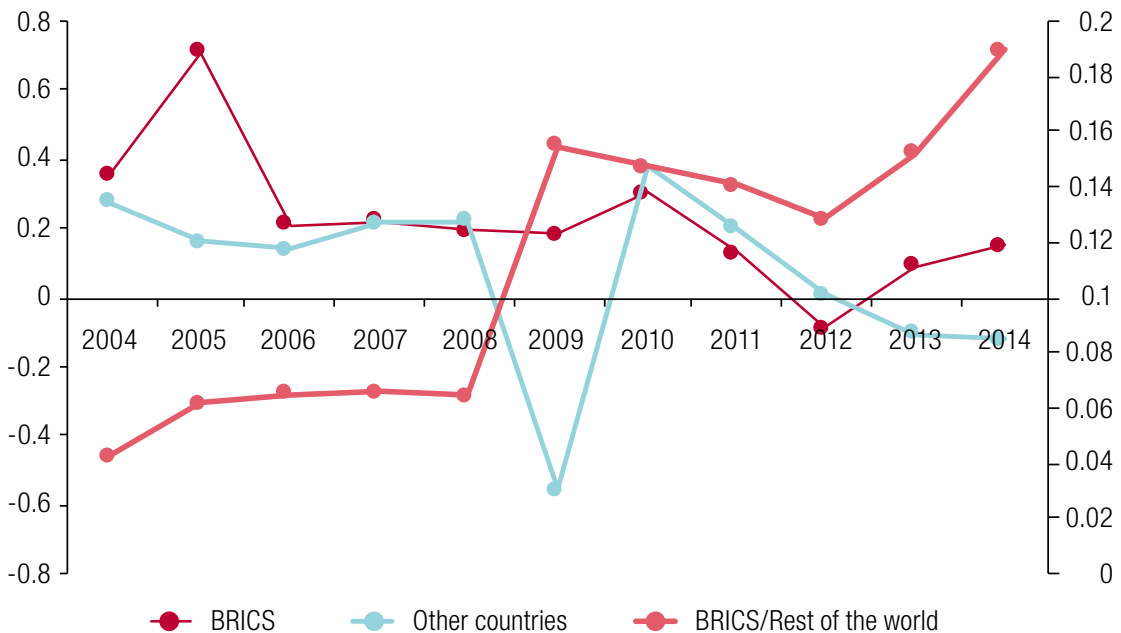

Source: Prepared by the authors, on the basis of data from the Government of Brazil, "Aliceweb2", n/d [online] http://comexstat. mdic.gov.br/pt/home.

a Country bloc formed by Brazil, the Russian Federation, India, China and South Africa. In this case, the analysis refers to the North-Eastern region of Brazil and the other BRICS countries excluding Brazil.

15 The subprime mortgage crisis of 2007 led to what became known as the United States financial crisis in 2008, which is seen as reflecting a profound crisis of confidence resulting from a chain of what were originally real estate loans made to insolvent borrowers. By causing economic agents to opt for liquidity and pay off their credits, this is driving banks and other financial firms into bankruptcy, even though they themselves are solvent (Bresser-Pereira, 2009, p. 133). 
Since 2004, China has been the main destination for exports from North-East Brazil to the other BRICS countries, followed by the Russian Federation, India and South Africa (see figure 2). The value of Chinese imports of products from North-East Brazil has been increasing steadily, and in 2014 it was more than 17 times the value traded in 2003. In contrast, the Russian Federation reduced its imports from the Brazilian North-East in 2007, and this situation persisted until 2012. Thereafter exports to the Russian Federation grew by $73.45 \%$ between 2013 and 2014. Even though the value of exports fell by $40.59 \%$ in 2007 and by $57.02 \%$ in 2012, foreign trade actually grew. Trade with the Russian Federation appears to be affected by natural constraints inherent to the production capacity of the North-Eastern region: in 2007 and 2009, exports of food, tobacco and beverages to that country came almost exclusively from the state of Alagoas (Government of Brazil, $\mathrm{n} / \mathrm{d}$ ). ${ }^{16}$

Figure 2

Trend of exports from North-East Brazil to the BRICS countries, ${ }^{a}$ 2003-2014

(Billions of dollars F.O.B.)

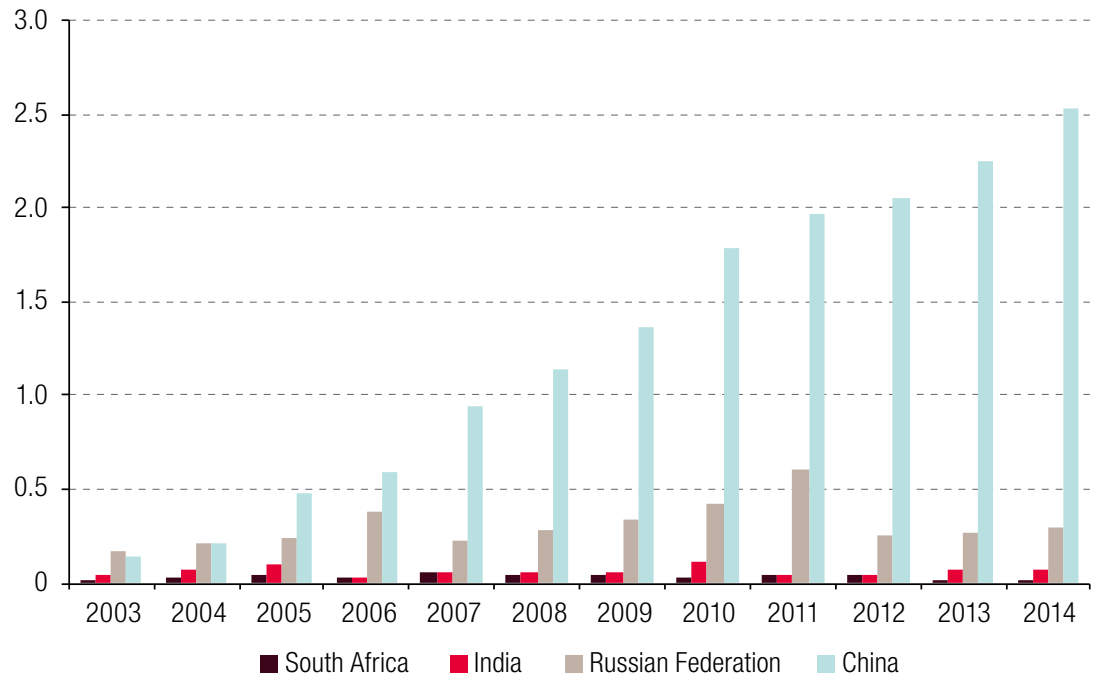

Source: Prepared by the authors, on the basis of data from Brazil Government, "Aliceweb2", n/d [online] http://comexstat.mdic. gov.br/pt/home.

a Country bloc formed by Brazil, the Russian Federation, India, China and South Africa. In this case, the analysis refers to the North-Eastern region of Brazil and the other BRICS countries excluding Brazil.

\section{Specialization coefficient}

According to the classification of products exported to the BRICS countries as measured by the specialization coefficient (SC), North-East Brazil displays specialization in low value added agricultural sectors (see table 1). A review of the two main destinations of exports from the North-East to the BRICS countries (China and the Russian Federation) shows that the most highly specialized foreign trade is concentrated in the food, tobacco and beverages category. Nearly all exports from the North-East to the Russian Federation belong to this group. Exports of food, tobacco and beverages to China have also risen to the top of the list of Chinese imports from North-East Brazil, especially since the 2008 financial crisis in the United States. That year also saw the strongest growth in the volume of exports from the North-East to the BRICS countries, driven mainly by Chinese imports. The chemicals specialization of the North-East's exports to India and South Africa reveals a trade channel involving a more complex and higher value-added product. After 2008, the profile of exports to India has become more diversified, favouring specialization in products in the basic metals, minerals and non-metallic minerals category. In the same period, exports to South Africa, which were mainly in the food, tobacco and beverages category, have been diversifying

\footnotetext{
${ }^{16}$ Nearly of the Russian Federation's imports from the Brazilian North-East are in the food, tobacco and beverages category.
} 
towards products in the minerals, footwear and leather categories. However, the overall volume of exports from the North-East to these two BRICS countries is minimal. Consequently, it can be argued that the impact of the BRICS countries on the export production profile of Brazil's North-Eastern region is very weak relative to the stimulus of investments in sectors with higher technological content and value-added.

Table 1

Specialization coefficient of exports from North-East Brazil to the BRICS countries ${ }^{a}$

\begin{tabular}{|c|c|c|c|c|c|c|c|c|c|c|}
\hline NBM/NCM sections ${ }^{b}$ & 2003 & Rank & 2008 & Rank & 2011 & Rank & 2013 & Rank & 2014 & Rank \\
\hline \multicolumn{11}{|l|}{ China } \\
\hline Food, tobacco and beverages & 0.1218 & 2 & 0.2711 & 2 & 0.3800 & 1 & 0.3542 & 1 & 0.3678 & 1 \\
\hline Paper and cellulose & 0.3296 & 1 & 0.3203 & 1 & 0.2845 & 2 & 0.2690 & 2 & 0.3382 & 2 \\
\hline Basic metals & 0.0603 & 8 & 0.0457 & 4 & 0.0908 & 4 & 0.2620 & 3 & 0.1161 & 3 \\
\hline Chemicals & 0.1148 & 3 & 0.0381 & 5 & 0.0177 & 7 & 0.0158 & 7 & 0.0687 & 4 \\
\hline Textiles & 0.0722 & 7 & 0.0264 & 7 & 0.1418 & 3 & 0.0342 & 4 & 0.0577 & 5 \\
\hline Shoes and leather & 0.0220 & 9 & 0.0272 & 6 & 0.0247 & 6 & 0.0247 & 5 & 0.0247 & 6 \\
\hline Minerals & 0.0859 & 5 & 0.2625 & 3 & 0.0464 & 5 & 0.0137 & 8 & 0.0149 & 7 \\
\hline Plastics and rubber & 0.1108 & 4 & 0.0065 & 8 & 0.0114 & 8 & 0.0069 & 9 & 0.0099 & 8 \\
\hline \multicolumn{11}{|l|}{ Russian Federation } \\
\hline Food, tobacco and beverages & 0.9901 & 1 & 0.9510 & 1 & 0.9818 & 1 & 0.9616 & 1 & 0.8930 & 1 \\
\hline Chemicals & 0.0002 & 4 & 0.0026 & 5 & 0.0003 & 6 & 0.0203 & 2 & 0.0788 & 2 \\
\hline Shoes and leather & 0.0087 & 2 & 0.0172 & 2 & 0.0129 & 2 & 0.0127 & 3 & 0.0105 & 3 \\
\hline Plastics and rubber & 0.0000 & 12 & 0.0086 & 4 & 0.0022 & 3 & 0.0003 & 5 & 0.0061 & 4 \\
\hline Textiles & 0.0008 & 3 & 0.0014 & 7 & 0.0010 & 5 & 0.0049 & 4 & 0.0056 & 5 \\
\hline \multicolumn{11}{|l|}{ India } \\
\hline Chemicals & 0.7256 & 1 & 0.5743 & 1 & 0.2706 & 2 & 0.2446 & 1 & 0.3551 & 1 \\
\hline Minerals & 0.0008 & 8 & 0.0008 & 9 & 0.1140 & 4 & 0.0237 & 9 & 0.1982 & 2 \\
\hline Shoes and leather & 0.0074 & 6 & 0.0021 & 8 & 0.0270 & 7 & 0.1082 & 4 & 0.1081 & 3 \\
\hline Transport equipment & 0.0000 & - & 0.0001 & 11 & 0.0003 & 10 & 0.0899 & 5 & 0.0725 & 4 \\
\hline Non-metallic minerals & 0.0108 & 5 & 0.0511 & 4 & 0.2883 & 1 & 0.1254 & 3 & 0.0575 & 5 \\
\hline Basic metals & 0.0000 & - & 0.0000 & - & 0.0001 & - & 0.2299 & 2 & 0.0492 & 6 \\
\hline Food, tobacco and beverages & 0.1739 & 2 & 0.2749 & 2 & 0.2105 & 3 & 0.0594 & 7 & 0.0491 & 7 \\
\hline Textiles & 0.0316 & 4 & 0.0133 & 6 & 0.0287 & 6 & 0.0204 & 10 & 0.0373 & 8 \\
\hline Plastics and rubber & 0.0468 & 3 & 0.0539 & 3 & 0.0557 & 5 & 0.0272 & 8 & 0.0352 & 9 \\
\hline \multicolumn{11}{|l|}{ South Africa } \\
\hline Minerals & 0.0129 & 8 & 0.0130 & 8 & 0.0000 & 13 & 0.0026 & 10 & 0.2774 & 1 \\
\hline Shoes and leather & 0.2092 & 2 & 0.0521 & 3 & 0.0799 & 4 & 0.2733 & 1 & 0.2077 & 2 \\
\hline Food, tobacco and beverages & 0.1121 & 3 & 0.6654 & 1 & 0.3321 & 1 & 0.2718 & 2 & 0.1400 & 3 \\
\hline Plastics and rubber & 0.0594 & 5 & 0.0416 & 5 & 0.1518 & 3 & 0.1678 & 3 & 0.1381 & 4 \\
\hline Chemicals & 0.4706 & 1 & 0.1298 & 2 & 0.3192 & 2 & 0.1611 & 4 & 0.1185 & 5 \\
\hline Machines and equipment & 0.0054 & 10 & 0.0267 & 6 & 0.0355 & 6 & 0.0616 & 5 & 0.0411 & 6 \\
\hline Basic metals & 0.0109 & 9 & 0.0446 & 4 & 0.0147 & 7 & 0.0205 & 6 & 0.0366 & 7 \\
\hline Textiles & 0.0268 & 7 & 0.0178 & 7 & 0.0618 & 5 & 0.0129 & 8 & 0.0239 & 8 \\
\hline
\end{tabular}

Source: Prepared by the authors, on the basis of data from Brazil Government, "Aliceweb2", n/d [online] http://comexstat.mdic. gov.br/pt/home.

Note: - not available.

a Country bloc formed by Brazil, the Russian Federation, India, China and South Africa. In this case, the analysis refers to the North-Eastern region of Brazil and the other BRICS countries excluding Brazil.

b Brazilian merchandise nomenclature / MERCOSUR Common Nomenclature.

\section{Revealed comparative advantage}

When combined with the specialization coefficient of the previous section, the indicator of revealed comparative advantage (RCA) demonstrates the external competitiveness of the products exported from the Brazilian North-East (see table 2). It is therefore unsurprising that the most competitive products are the same as those in which the region specializes. The North-Eastern region displays a level of competitiveness well above the world average for the following product categories: food, tobacco and 
beverages; paper and pulp; and footwear and leather. All of those exports are the result of trade with the BRICS countries. The competitiveness of the food, tobacco and beverages group stems mainly from exports to the Russian Federation, which is the second largest destination for exports from North-East Brazil. In trade with China, which is the main destination of exports from the North-East, the food, tobacco and beverage group has become relatively more competitive, especially since the 2008 crisis. However, it is in paper and pulp that the North-East is most competitive in trade with China, as also reported by Feistel and Hidalgo (2011) for that country. The product categories which are most competitive in exports from the North-East to India and South Africa are chemicals; plastics and rubber; and footwear and leather. Although South Africa is one of the destinations receiving the lowest volume of exports from Brazil's North-East, the advantage of footwear and leather products exported to that market is at least ten times greater than that of the rest of the world. In general, the effect of the BRICS countries on the foreign trade of the North-East changes the regional production matrix very little.

Table 2

Revealed comparative advantage of exports from North-East Brazil to the BRICS countries ${ }^{a}$ by product category

\begin{tabular}{|c|c|c|c|c|c|c|c|c|c|c|c|c|}
\hline NBM/NCM sections ${ }^{b}$ & 2003 & 2004 & 2005 & 2006 & 2007 & 2008 & 2009 & 2010 & 2011 & 2012 & 2013 & 2014 \\
\hline \multicolumn{13}{|l|}{ China } \\
\hline Paper and cellulose & 47.68 & 43.58 & 34.89 & 36.69 & 19.33 & 44.11 & 41.44 & 38.09 & 33.25 & 31.43 & 30.02 & 36.35 \\
\hline $\begin{array}{l}\text { Food, tobacco and } \\
\text { beverages }\end{array}$ & 2.59 & 2.76 & 8.04 & 9.22 & 7.48 & 9.99 & 7.52 & 5.99 & 12.31 & 11.07 & 11.97 & 12.42 \\
\hline Basic metals & 1.22 & 0.81 & 0.27 & 0.91 & 3.76 & 0.72 & 3.90 & 2.42 & 1.64 & 1.52 & 4.93 & 2.11 \\
\hline Chemicals & 2.71 & 3.29 & 1.28 & 1.39 & 2.14 & 0.79 & 1.03 & 1.01 & 0.35 & 1.32 & 0.36 & 1.47 \\
\hline Minerals & 2.96 & 9.07 & 8.56 & 9.29 & 10.67 & 10.29 & 0.97 & 13.10 & 2.43 & 4.05 & 0.81 & 0.91 \\
\hline Shoes and leather & 0.35 & 0.82 & 0.83 & 1.02 & 0.82 & 0.72 & 0.64 & 0.57 & 0.57 & 0.48 & 0.55 & 0.55 \\
\hline Textiles & 0.43 & 0.34 & 0.60 & 0.33 & 0.30 & 0.21 & 0.21 & 0.32 & 1.12 & 1.19 & 0.28 & 0.47 \\
\hline Plastics and rubber & 3.87 & 1.60 & 1.86 & 1.36 & 0.18 & 0.22 & 1.79 & 0.17 & 0.32 & 0.28 & 0.18 & 0.26 \\
\hline Non-metallic minerals & 2.44 & 0.88 & 0.01 & 0.02 & 0.35 & 0.03 & 0.99 & 0.55 & 0.04 & 0.27 & 0.29 & 0.01 \\
\hline \multicolumn{13}{|l|}{ Russian Federation } \\
\hline $\begin{array}{l}\text { Food, tobacco and } \\
\text { beverages }\end{array}$ & 49.19 & 72.4 & 61.48 & 57.7 & 40.9 & 53.0 & 32.0 & 51.5 & 44.8 & 29.3 & 31.2 & 23.5 \\
\hline Chemicals & 0.00 & 0.07 & 0.05 & 1.66 & 0.16 & 0.06 & 0.04 & 0.01 & 0.00 & 0.60 & 0.44 & 1.84 \\
\hline Shoes and leather & 4.43 & 3.21 & 4.13 & 3.35 & 13.7 & 23.9 & 13.1 & 17.8 & 14.3 & 19.0 & 8.65 & 8.06 \\
\hline Textiles & 0.17 & 0.33 & 0.74 & 0.81 & 1.31 & 1.48 & 0.73 & 1.15 & 3.03 & 5.62 & 3.40 & 3.32 \\
\hline \multicolumn{13}{|l|}{ India } \\
\hline Shoes and leather & 0.20 & 0.21 & 0.06 & 0.86 & 0.21 & 0.09 & 0.28 & 0.22 & 1.51 & 4.78 & 5.29 & 4.75 \\
\hline Paper and cellulose & 0.00 & 0.00 & 0.00 & 0.08 & 0.44 & 1.45 & 0.78 & 0.79 & 0.00 & 0.01 & 0.01 & 4.05 \\
\hline Chemicals & 7.04 & 5.28 & 5.16 & 6.89 & 8.47 & 5.48 & 4.46 & 5.90 & 2.98 & 2.26 & 2.33 & 3.34 \\
\hline Plastics and rubber & 1.57 & 1.15 & 2.17 & 3.01 & 1.49 & 2.19 & 9.33 & 0.60 & 2.09 & 1.95 & 0.99 & 1.37 \\
\hline Minerals & 0.01 & 0.52 & 0.56 & 0.01 & 0.01 & 0.00 & 0.03 & 0.03 & 0.54 & 1.45 & 0.11 & 0.96 \\
\hline Basic metals & 0.00 & 0.00 & 0.00 & 0.99 & 0.00 & 0.00 & 0.00 & 0.08 & 0.00 & 0.47 & 5.06 & 0.95 \\
\hline Transport equipment & 0.00 & 0.02 & 0.03 & 0.00 & 0.01 & 0.00 & 0.00 & 0.00 & 0.00 & 0.05 & 1.39 & 0.89 \\
\hline $\begin{array}{l}\text { Food, tobacco } \\
\text { and beverages }\end{array}$ & 1.48 & 2.49 & 2.92 & 0.61 & 0.35 & 2.65 & 3.50 & 3.55 & 2.13 & 0.44 & 0.47 & 0.40 \\
\hline Non-metallic minerals & 0.05 & 0.05 & 0.04 & 0.13 & 0.22 & 0.31 & 0.30 & 0.28 & 1.45 & 0.99 & 0.74 & 0.35 \\
\hline \multicolumn{13}{|l|}{ South Africa } \\
\hline Shoes and leather & 29.3 & 27.62 & 13.0 & 10.2 & 10.1 & 15.0 & 23.1 & 17.4 & 15.1 & 17.4 & 35.9 & 24.8 \\
\hline Plastics and rubber & 2.78 & 6.30 & 3.56 & 5.22 & 2.46 & 2.40 & 2.58 & 7.80 & 7.75 & 3.53 & 7.59 & 5.24 \\
\hline Minerals & 0.09 & 0.12 & 0.77 & 0.70 & 0.36 & 0.07 & 0.00 & 0.03 & 0.00 & 0.00 & 0.01 & 1.73 \\
\hline Chemicals & 7.12 & 6.00 & 4.07 & 5.23 & 2.79 & 1.93 & 1.09 & 4.75 & 5.57 & 0.78 & 2.67 & 1.68 \\
\hline Textiles & 1.04 & 0.79 & 0.61 & 1.66 & 0.56 & 2.00 & 0.58 & 1.08 & 5.07 & 1.15 & 0.95 & 1.56 \\
\hline $\begin{array}{l}\text { Food, tobacco and } \\
\text { beverages }\end{array}$ & 1.08 & 2.21 & 4.01 & 3.73 & 8.43 & 8.46 & 6.77 & 3.23 & 3.85 & 7.67 & 2.70 & 1.18 \\
\hline Paper and cellulose & 2.20 & 0.00 & 0.72 & 0.00 & 0.00 & 0.06 & 0.00 & 0.65 & 0.00 & 0.00 & 0.75 & 0.03 \\
\hline
\end{tabular}

Source: Prepared by the authors, on the basis of data from Brazil Government, "Aliceweb2", n/d [online] http://comexstat.mdic. gov.br/pt/home.

a Country bloc formed by Brazil, the Russian Federation, India, China and South Africa. In this case, the analysis refers to the North-Eastern region of Brazil and the other BRICS countries excluding Brazil.

b Brazilian merchandise nomenclature / MERCOSUR Common Nomenclature. 


\section{Contribution to the trade balance (CTB)}

The comparative advantage measured by the contribution to the trade balance (CTB) indicator presented in this research ranks the categories of products exported from the Brazilian North-East to the BRICS countries by their contribution to the region's trade balance (see table 3). The relative advantages indicated for the food, tobacco and beverages category are common to all BRICS countries, with a trade balance that exceeds the region's theoretical trade balance. Nonetheless, the greatest trade advantages can be seen in the two main destinations of exports from North-East Brazil, namely China and the Russian Federation. The second and third groups of products with the greatest trade advantage in exports to China are, respectively, paper and pulp (the most specialized product in the North-East's trade with that country until 2008) and basic metals. The main products imported by the Russian Federation pertain to the food, tobacco and beverages group, so it is not surprising that this group made the largest contribution to the North-East's trade balance with that country. There are four other products with a comparative advantage in the trade balance, albeit with a much lower relative value, namely: chemicals, non-metallic materials, basic metals and plastics, and rubber. In foreign trade with India and South Africa, the product categories that make the largest contribution to the region's trade balance are more diversified, although the overall share of exports to these countries is very small. Even so, the following categories have an advantage in comparison with the trade balance: minerals, chemicals, machinery and equipment, Basic metals and textiles, to mention only the most important commodities.

Table 3

Contribution to the trade balance made by exports from North-East Brazil to the BRICS countries, ${ }^{\text {a }} 2014$

\begin{tabular}{lcccc}
\hline NBM/NCM sections $^{b}$ & China & Russian Federation & India & South Africa \\
\hline Food, tobacco and beverages & 7.95 & 39.20 & 1.45 & 4.38 \\
\hline Minerals & 0.14 & -3.70 & 20.34 & 18.79 \\
\hline Chemicals & 0.56 & 4.53 & 10.91 & 17.97 \\
\hline Plastics and rubber & 0.18 & 1.24 & 2.33 & 4.84 \\
\hline Shoes and leather & 0.27 & 0.20 & 1.09 & 5.59 \\
\hline Wood and charcoal & 0.00 & 0.00 & 0.01 & 0.10 \\
\hline Paper and cellulose & 6.82 & 0.04 & 0.26 & 2.04 \\
\hline Textiles & 0.27 & 0.10 & 8.17 & 0.61 \\
\hline Non-metallic minerals & -0.61 & 2.47 & 2.59 & 4.65 \\
\hline Basic metals & 1.29 & 2.35 & 1.67 & 13.95 \\
\hline Machines and equipment & -5.54 & 0.10 & 5.16 & 8.84 \\
\hline Transport equipment & 0.14 & 0.10 & 2.26 & 0.78 \\
\hline Optics and instruments & 0.06 & 0.01 & 0.53 & 0.02 \\
\hline Others & 0.09 & 0.00 & 0.05 & 0.02 \\
\hline
\end{tabular}

Source: Prepared by the authors, on the basis of data from Brazil Government, "Aliceweb2", n/d [online] http://comexstat.mdic. gov.br/pt/home.

a Country bloc formed by Brazil, the Russian Federation, India, China and South Africa. In this case, the analysis refers to the North-Eastern region of Brazil and the other BRICS countries excluding Brazil.

b Brazilian merchandise nomenclature / MERCOSUR Common Nomenclature.

\section{Degree of intraindustry trade}

Based on the indicator of the degree of intraindustry trade (GL) in the main products exported from the Brazilian North-East to the two most important BRICS export destinations, it is easy to see that trade between industries (interindustry trade) is the predominant characteristic (see table 4). The two main products exported to China, according to the specialization coefficients presented in section IV.2, belong to the paper and pulp and food, tobacco and beverages categories. The GL index for these two groups 
in regional exports to China is much lower than the parameter of intraindustry activity, which is above 0.5. The only product groups that showed an intraindustry trade pattern were those of low-concentration Chinese imports originating in the Brazilian North-East: minerals, chemicals, footwear and leather and basic metals. Trade with the Russian Federation is predominantly interindustry in all products exported. In foreign trade with India, a large proportion of the exported products are intraindustry. However, India and South Africa are the BRICS countries that import the least from Brazil's North-Eastern region. It can thus be said that exports from the North-East are basically explained by relative factor endowments, as per the Heckscher-Ohlin model (Ohlin, 1967). This result is also consistent with the analysis made by Feistel and Hidalgo (2011).

Table 4

Degree of intraindustry trade in exports from North-East Brazil to the BRICS countries, ${ }^{\text {a }} 2014$

\begin{tabular}{lcccc}
\hline NBM/NCM sections $^{b}$ & China & Russian Federation & India & South Africa \\
\hline Food, Tobacco and Beverages $^{\text {Minerals }}$ & 0.11 & 0.00 & 0.60 & 0.34 \\
\hline Chemicals & 0.92 & 0.00 & 0.02 & 0.63 \\
\hline Plastics and rubber & 0.80 & 0.32 & 0.56 & 0.17 \\
\hline Shoes and leather & 0.30 & 0.17 & 0.27 & 0.53 \\
\hline Wood and charcoal & 0.75 & 0.00 & 0.22 & 0.00 \\
\hline Paper and cellulose & 0.04 & 0.00 & 0.00 & 0.00 \\
\hline Textiles & 0.05 & 0.00 & 0.72 & 0.01 \\
\hline Non-metallic minerals & 0.60 & 0.00 & 0.08 & 0.05 \\
\hline Basic metals & 0.00 & 0.00 & 0.39 & 0.04 \\
\hline Machines and equipment & 0.57 & 0.01 & 0.53 & 0.09 \\
\hline Transport equipment & 0.00 & 0.03 & 0.06 & 0.20 \\
\hline Optics and instruments & 0.05 & 0.00 & 0.57 & 0.50 \\
\hline Others & 0.00 & 0.00 & 0.00 & 0.64 \\
\hline Source: Prepared
\end{tabular}

Source: Prepared by the authors, on the basis of data from Brazil Government, "Aliceweb2", n/d [online] http://comexstat.mdic. gov.br/pt/home.

a Country bloc formed by Brazil, the Russian Federation, India, China and South Africa. In this case, the analysis refers to the North-Eastern region of Brazil and the other BRICS countries excluding Brazil.

b Brazilian merchandise nomenclature / MERCOSUR Common Nomenclature.

\section{Conclusions}

In view of the economic importance of foreign trade for the development of North-East Brazil and the importance of the BRICS countries for Brazil's foreign trade, this article has analysed the influence of these countries on the productive restructuring of the North-East by specialization groups. It also reviewed the relative competitiveness of commodities produced in the North-East and the type of trade activity measured by the degree of intraindustry trade. According to the classification by specialization group, there has been little restructuring of North-Eastern exports, and this has only a minimal effect on the relative importance of the categories of products exported to the BRICS countries. On average, exports to the BRICS countries display revealed comparative advantages, especially in the case of product categories with a higher trade concentration or specialization coefficient. Nonetheless, the intraindustry trade result makes clear that these competitive advantages in trade with the BRICS countries arise mainly from relative factor endowments.

These countries have not caused major changes in the production and foreign trade matrix of the North-Eastern region, nor have they influenced high value added production sectors or those invested in technology-intensive products. On the contrary, the Brazilian North-East's foreign trade with the BRICS countries exploits a historical feature of the regional economy, through its near-exclusive focus on the commodities in the food and mineral sectors, produced with comparative advantage in 
North-East Brazil. The results clearly show that the expansion of trade between the Brazilian North-East and the BRICS countries preserves one of the key features of the regional economy, namely specialization in producing and exporting food products.

China is the country in this group that imported the most products from the North-East, concentrated in the food, tobacco and beverages, and paper and pulp categories, in which North-East Brazil has a comparative advantage. The Russian Federation represents the second largest market for the region's exports, absorbing products from the food, tobacco and beverages sector almost exclusively. While the other countries have a more diversified trade in products from the Brazilian North-East, the overall volume of exports to India and South Africa is negligible. Trade with India is stimulating demand in the chemicals sector; and the recent focus on the minerals, footwear and leather groups followed the intensification of trade in 2008. Exports from the North-East to South Africa are more varied and encompass minerals; footwear and leather; food, tobacco and beverages; plastics and rubber; and chemicals. All these products had a specialization ratio of more than 0.10 in 2014.

The indicator of contribution to the trade balance showed that trade between the BRICS and the North-East of Brazil contributed positively to the region's balance of trade. It was found that the North-Eastern region has a revealed comparative advantage in trade with the BRICS countries for various product groups. Nonetheless, policies are needed not only to maintain these advantages, but also to enable the products in question to gain greater traction in the markets of India, South Africa and the Russian Federation. Exports to these economies have grown far more slowly than trade with China. The formulation of trade policies to exploit comparative advantages in plastics and rubber for India, footwear and leather for the Russian Federation, and textiles for South Africa and the Russian Federation, is seen as essential.

\section{Bibliography}

Almeida, J. E. de and J. B. de Araújo (2004), "Um modelo exaurido: a experiência da SUDENE", Teoria e Evidência Econômica, vol. 12, No. 23, Passo Fundo, University of Passo Fundo.

Balassa, B. (1965), "Trade liberalisation and 'revealed' comparative advantage", The Manchester School of Economics and Social Science, vol. 33, No. 2, Oxford, Blackwell Publishing.

Bresser-Pereira, L. C. (2009), "A crise financeira de 2008", Brazilian Journal of Political Economy, vol. 29, No. 1, São Paulo, Centre for Political Economy.

Caldarelli, C. E. and S. H. G. Miranda (2009), "Restrições comerciais e comércio intraindustry: uma análise usando modelo LOGIT", Forty-seventh Congress of the Brazilian Society of Rural Economics, Administration and Rural (SOBER), Porto Alegre, 26-30 July.

Carbaugh, R. J. (2004), Economia internacional, São Paulo, Pioneira Thomson Learning.

Carvalho, D. B., R. de Melo Caldas and J. P. R. Lima (2013), "Potencialidade e efetividade das relações comerciais entre o Nordeste do Brasil e o Mercosul", Revista Econômica do Nordeste, vol. 44, No. 2, Fortaleza, Bank of Northeast Brazil.

Carvalho, E. B. and R. S. C. Alves (2006), "Concentração das exportações e vulnerabilidade no Nordeste brasileiro", paper presented at the Forty-fourth Congress of the Brazilian Society of Rural Economics, Management and Sociology (SOBER), Fortaleza, 23-27 July.

Diniz, C. (2009), "Celso Furtado e o desenvolvimento regional", Nova Economia, vol. 19, No. 2, Belo Horizonte, Federal University of Minas Gerais.

Feistel, P. R. and Á. B. Hidalgo (2011), "O intercâmbio comercial Nordeste-China: desempenho e perspectivas", Revista Econômica do Nordeste, vol. 42, No. 4, Fortaleza, Bank of Northeast Brazil. (2007), "O intercâmbio comercial Nordeste-Mercosul: a questão das vantagens comparativas", Revista Econômica do Nordeste, vol. 38, No. 1, Fortaleza, Bank of Northeast Brazil.

Furtado, C. (1997), Formação econômica do Brasil, São Paulo, Editora Atlas.

Gomes, G. M. and J. R. Vergolino (1995), "A macroeconomia do desenvolvimento nordestino: 1960/1994", Texto para Discussão, No. 372, Brasilia, Institute for Applied Economic Research (IPEA). 
Government of Brazil (n/d), "Aliceweb2" [online] http://comexstat.mdic.gov.br/pt/home.

Grubel, H. G. and P. J. Lloyd (1975), Intraindustry Trade: The Theory and Measurement of International Trade in Differentiated Products, London, Macmillan.

GTDN (Working Group for the Development of the Northeast) (1959), Uma política de desenvolvimento para o Nordeste, Rio de Janeiro, National Press Department.

Guimarães Neto, L. (1997), "Trajetória econômica de uma região periférica", Estudos Avançados, vol. 11, No. 29, São Paulo, University of São Paulo.

Helpman, E. and P. Krugman (1985), Market Structure and Foreign Trade: Increasing Returns, Imperfect Competition, and the International Economy, Cambridge, MIT Press.

Hidalgo, Á. B. (2000), "Exportações do Nordeste do Brasil: crescimento e mudança na estrutura", Revista Econômica do Nordeste, vol. 31, número especial, Fortaleza, Bank of Northeast Brazil.

(1993), "Mudanças na estrutura do comércio internacional brasileiro: comércio interindústria x comércio intraindústria", Análise Econômica, vol. 11, No. 20, Porto Alegre, Federal University of Rio Grande do Sul.

Hidalgo, Á. B. and D. F. P. G. da Mata (2005), "Inserção das regiões brasileiras no comércio internacional: os casos da Região Nordeste e do Estado de Pernambuco", Ensaios FEE, vol. 26, No. 2, Porto Alegre, Foundation of Economics and Statistics Siegfried Emanuel Heuser.

Hidalgo, Á. B. and M. F. Sales (2014), "Abertura comercial e desigualdade de rendimentos: análise para as regiões brasileiras", Revista de Economia Contemporânea, vol. 18, No. 3, Rio de Janeiro, Federal University of Río de Janeiro (UFRJ).

ITC (International Trade Centre) (n/d), "Trademap" [online] http://www.trademap.org.

Kocourek, A. (2015), "Structural changes in comparative advantages of the BRICS", Procedia -Social and Behavioral Sciences, No. 172, Amsterdam, Elsevier.

Lafay, G. (1990), "La mesure des avantages comparatifs révélés: exposé de la méthodologie du SCPIl", Économie prospective internationale, vol. 41, No. 2, Paris, Center for International Prospective Studies.

Lima, J. P. R. (1998), "A abertura comercial, rebatimentos regionais e o planejamento: o Nordeste em realce", Revista Análise Econômica, vol. 16, No. 29, Porto Alegre, Federal University of Rio Grande do Sul.

Marques, J. J. S. and others (2017), "Competitividade das exportações de castanha de caju e o efeito da crise de 2008 nas suas exportações no Brasil", unpublished.

Mathur, S. and M. Dasgupta (2013), BRICS: Trade Policies, Institutions and Areas for Deepening Cooperation, New Delhi, Indian Institute of Foreign Trade.

MRE (Ministry of Foreign Affairs) (2015), BRICS Comércio Exterior, Brasilia.

Ohlin, B. (1967), Interregional and International Trade, Cambridge, Harvard University Press.

Reis, M. E. F. (2012), "BRICS: surgimento e evolução", O Brasil, os Brics e a agenda internacional, Brasilia, Alexandre de Gusmão Foundation.

Ricardo, D. (1982), Principios de economia política e tributação, São Paulo, Victor Civita.

Salvatore, D. (2000), Economia internacional, Rio de Janeiro, LTC.

Samuelson, P. A. (1948), "International trade and the equalisation of factor prices", The Economic Journal, vol. 58, No. 230, Oxford, Royal Economic Society.

Sicsú, A. B. and T. Bacelar (1994), O GTDN: da proposta à realidade: ensaios sobre a questão regional, Recife, Editora Universitária UFPE.

Smith, A. (1996), A riqueza das nações: investigação sobre a natureza e suas causas, São Paulo, Nova Cultural.

Souza, A. C. L. M. and others (2014), "BRICS e o comércio exterior cearense", IPESC Informe, No. 79, Fortaleza, Ceará Research Institute on Economic Strategy. 